\title{
THE ROLE OF GEOGRAPHY IN SHAPING GOVERNANCE PERFORMANCE
}

Anthony Baluga and Bruno Carrasco

NO. 73

December 2020

\section{ADB SUSTAINABLE DEVELOPMENT WORKING PAPER SERIES}





\section{ADB Sustainable Development Working Paper Series}

\section{The Role of Geography in Shaping Governance Performance}

Anthony Baluga and Bruno Carrasco

No. 73 | December 2020
Anthony Baluga is an economics consultant and Bruno Carrasco is Chief of the Governance Thematic Group, Sustainable Development and Climate Change Department, ADB. 
(C) 2020 Asian Development Bank 6 ADB Avenue, Mandaluyong City, 1550 Metro Manila, Philippines

Tel +632 8632 4444; Fax +63286362444

www.adb.org

Some rights reserved. Published in 2020.

Publication Stock No. WPS200378

DOI: http://dx.doi.org/10.22617/WPS200378

The views expressed in this publication are those of the authors and do not necessarily reflect the views and policies of the Asian Development Bank (ADB) or its Board of Governors or the governments they represent.

ADB does not guarantee the accuracy of the data included in this publication and accepts no responsibility for any consequence of their use. The mention of specific companies or products of manufacturers does not imply that they are endorsed or recommended by ADB in preference to others of a similar nature that are not mentioned.

By making any designation of or reference to a particular territory or geographic area, or by using the term "country" in this document, $A D B$ does not intend to make any judgments as to the legal or other status of any territory or area.

This work is available under the Creative Commons Attribution 3.0 IGO license (CC BY 3.0 IGO)

https://creativecommons.org/licenses/by/3.0/igo/. By using the content of this publication, you agree to be bound by the terms of this license. For attribution, translations, adaptations, and permissions, please read the provisions and terms of use at https://www.adb.org/terms-use\#openaccess.

This CC license does not apply to non-ADB copyright materials in this publication. If the material is attributed to another source, please contact the copyright owner or publisher of that source for permission to reproduce it. ADB cannot be held liable for any claims that arise as a result of your use of the material.

Please contact pubsmarketing@adb.org if you have questions or comments with respect to content, or if you wish to obtain copyright permission for your intended use that does not fall within these terms, or for permission to use the ADB logo.

The ADB Sustainable Development Working Paper Series presents data, information, and/or findings from ongoing research and studies to encourage exchange of ideas and elicit comment and feedback about development issues in Asia and the Pacific. Since papers in this series are intended for quick and easy dissemination, the content may or may not be fully edited and may later be modified for final publication.

Corrigenda to ADB publications may be found at http://www.adb.org/publications/corrigenda.

Notes:

In this publication, “\$” refers to United States dollars. 


\section{CONTENTS}

TABLES AND FIGURES

ACKNOWLEDGMENTS V v

ABSTRACT

$\begin{array}{lll}\text { I. INTRODUCTION } & 1\end{array}$

II. SPATIAL CONSIDERATIONS ON GOVERNANCE 2

III. MEASURES OF SPATIAL AUTOCORRELTION 3

A. Moran's I 3

B. Spatial Econometric Technique 4

C. Interpreting the Parameter Estimates 5

D. Related Studies 6

IV. DEFINING VARIABLES AND DATA REQUIREMENTS 6

$\begin{array}{llr}\text { V. } & \text { RESULTS OF SPATIAL ANALYSIS } & 8\end{array}$

A. Geographical Dependencies Exist $\quad 8$

B. Spatial Spillover Most Evident in the Political Regime Dimension 9

C. Income Level Significantly Determines Governance Performance 10

D. Feedback Effects of Income Level on Governance Performance 11

E. Other Drivers of Country Governance Performance 12

$\begin{array}{lr}\text { VI. CONCLUSIONS } & 13\end{array}$

A. Summary of Key Findings 13

B. Policy Applications 13

APPENDIX 1: DEFINITIONS OF WORLDWIDE GOVERNANCE INDICATORS 15

APPENDIX 2: SPATIAL REGRESSION RESULTS 16

$\begin{array}{lr}\text { REFERENCES } & 20\end{array}$ 


\section{TABLES AND FIGURES}

\section{TABLES}

1 Worldwide Governance Indicators-Dimensions and Criteria $\quad 7$

2 Measuring Governance Spatial Spillover 9

3 Determinants of Governance 11

\section{FIGURES}

1 Illustration of the Weight Matrix Based on Distance 5

2 A Measure of Spatial Autocorrelation-Moran's I 8 


\section{ACKNOWLEDGMENTS}

We acknowledge valuable comments from Hiranya Mukhopadhyay, principal public management specialist, and Cigdem Akin, senior public management economist, from the Central and West Asia Department, as well as Arjun Goswami, chief of regional cooperation and integration thematic group, from the Sustainable Development and Climate Change Department, of the Asian Development Bank. Insightful feedback from participants of the 2020 Asian Development Bank Economists Forum session on institutions and the North American Resident Office Governance and Development Outcomes Seminar series are also highly appreciated. We also recognize the research assistance provided by Ernalyn Lising, consultant, and editing work of Ma. Antoinette Figurasin from the Sustainable Development and Climate Change Department of the Asian Development Bank. 


\begin{abstract}
This paper explores empirically the influence of geography on governance. While income is commonly accepted to influence governance, the influence of geography-while intuitive-is less well understood, including the decomposition across the dimensions of governance. Voice and accountability is derived as the dimension of governance that neighboring countries are most likely to influence-based on the Worldwide Governance Indicators 2019 and the hypothesis of Tobler (1970) that "everything is related to everything else, but near things are more related than distant things" and using a spatial autocorrelation model. This paper also reviews empirically other determinants of institutional quality and points to a country's income per capita having significant positive direct and indirect impact on neighborhood governance performance. Recognizing the role of spatial spillover provides a persuasive argument in favor of strengthening institutions of regionalism to share ideas and transfer know-how more actively across borders for improved governance outcomes.
\end{abstract}

JEL Classification Codes: H00, O10, O38, C13, C51, E60 


\section{INTRODUCTION}

The idea that governance matters is well-known to development practitioners. In the early 1990s, the prevailing view suggested that economic growth combined with good governance and control of corruption would improve the efficiency of labor, attract private investment, and lead to poverty alleviation and improved well-being. This narrative has evolved to one where inclusive and sustainable economic growth with strengthened governance and capacity development will lead to poverty alleviation and improve development outcomes.

The good governance agenda has evolved over the years and has transitioned from a focus on institutions, largely influenced by work from North (1971), to anti-corruption (Murphy et al. 1993; Mauro 1995; Ades and Di Tella 1996), to more recently, service delivery and capacity strengthening (Holmberg et al. 2009; Moloney 2009).

In various studies examining cross-country differences in governance, geography is often considered as an important driver of governance performance. Variables like latitude; climate; temperature; country size; climate-related diseases; or "dummies" indicating that a country is landlocked, is composed of islands, or belongs to a particular region are commonly used as proxies for geography (Acemoglu et al. 2001, 2002; Easterly and Levine 2003; Rodrik et al. 2004; Olsson and Hibbs 2005).

However, these studies ignore the possibility that cross-country data may be characterized by spatial dependence. According to Anselin (2006): "Spatial dependence is a special case of cross-sectional dependence, in the sense that the structure of the correlation or covariance between observations at different locations is derived from a specific ordering, determined by the relative position (distance, spatial arrangement) of the observations in geographic space."

This paper seeks to explain not simply whether geography matters, but how it matters. Geography in this paper is understood to reflect locational proximity and will be more formally represented by spatial dependence. Several justifications have been put forward to explain why the geography-governance nexus may be characterized by spatial dependence. Like certain macroeconomic phenomena, governance may have a spatial dimension due to spillovers and resource flows across juridical boundaries. Other possible factors that may cause spatial dependence include policy convergence (Mukand and Rodrik 2005), interdependence of policy decisions (Brueckner 2003), or transmission of government forms (Starr 1991).

This paper takes on a development economics approach to governance defined as "the manner in which power is exercised in the management of economic and social resources for development" (World Bank 1992). Using the governance indicators of Kaufmann et al. (2009), this study examines the existence of spatial dependence. It also builds substantially from the literature survey, methodology, and findings of similar studies conducted by Hosseini and Kaneko (2012), and Seldadyo et al. (2010).

The findings, as presented in the paper, show that governance in a given country exhibits a positive relationship with governance in neighboring countries. It was observed that well- (or poorly) governed countries are geographically clustered with other well- (or poorly) governed countries. The effect of spatial spillover fades with distance from the country in question. This study also reviews the transmission mechanisms that can possibly explain the governance spatial spillovers. The results also highlight important policy considerations that can help to influence results in public policy.

A simple word count of ADB's Operational Priority 6, Strengthening Governance and Capacity Development under Strategy 2030 reveals 193 references to institutions, 139 to capacity development, and 72 to corruption. 
The remainder of the paper is organized as follows: Section II offers some theoretical background, Section III introduces spatial autocorrelation measurement techniques that operationalize spatial dependence empirically, Section IV presents the variables and data needs, Section 5 reports and discusses the results of the empirical analysis, and Section 6 provides conclusions.

\section{SPATIAL CONSIDERATIONS ON GOVERNANCE}

The idea of cross-country governance performance having a spatial dimension is akin to the interpretation of "interdependence of players" in the Coase Theorem. Coase (1960) theorizes that different social players in a society are connected by virtue of their interdependence rather than externalities. Interdependence exists when a choice of one agent influences that of another. This situation is often overlooked in conventional economic analysis, which assumes that agents are independent of one another.

In their geography and governance study, Seldadyo et al. (2009) gave detailed theoretical underpinnings of the dynamic governance relationships across jurisdictions, especially within certain country groupings. Recently, strategic interaction among governments has become a major focus of theoretical work. For instance, in the tax-competition literature, governments levy a tax rate that is inversely related to its mobile tax base (i.e., the higher the mobility of a jurisdiction's tax base, the lower the applied tax rate). This government taxation approach ${ }^{2}$ occurs when Tiebout competition across jurisdictions leads to citizen tax payers to vote with their feet (Brueckner 2000). Likewise, governments may compete in many other areas than taxes. There is, for instance, an extensive literature on how governments may compete across jurisdictions to lower cost of, say, doing business to attract foreign direct investment (FDI). For instance, Globerman and Shapiro (2002) find that governance is an important determinant of both FDI inflows and outflows. Good governance creates the conditions which incentivizes multinational corporations to emerge from their home base and invest abroad.

However, the possible interaction between governments with respect to governance strategies has not been fully researched. Brueckner (2003) presented a general theoretical framework that elaborated further on this strand of literature.

The focus is on one of Brueckner's theoretical models that underlies some of the empirical studies on government interaction known as the spillover model. In this model, the government of country $i$ selects the level of a decision variable $z_{i}$, which in our case refers to governance. But country i's governance preference is also directly affected by the $z$ 's chosen by other countries, often referred to as yardstick competition. In other words, spillovers exist, and one country's governance performance level or governance quality is likely to have some influence on a neighboring country's own governance performance.

2 In a region where citizens are able to move freely from one jurisdiction to another, the imposition of higher tax rates in one area relative to neighboring states often leads to citizens opting to leave the said jurisdiction and transfer to a state with lower tax regimes. 
In formal terms, country i's objective function, $V$, is written as:

$$
V=F\left(z_{i}, z_{j} ; X_{i}\right)
$$

- $\quad$ where $z_{j}$ is the vector of $z$ 's for other countries, and

- $\quad X_{i}$ is a vector of characteristics of country $i$ that determine preferences.

Country $i$ chooses $z_{i}$ to maximize equation (1), setting $\partial V / \partial z_{i}=0$. Since this derivative depends on $z_{j}$ and $X_{i}$, the optimal $z_{i}$ depends on choices of other countries as well as country $i$ 's characteristics. So, the solution can be written as:

$$
z_{i}=R\left(z_{j} ; X_{i}\right)
$$

The function $R$ represents a reaction function, which gives country $i$ 's best response to the choices of other countries. Brueckner showed that this spillover model indeed reflects the intuition in various empirical studies on government interaction concerning government spending, taxes, and environmental policies that are based on spillover models.

To properly undertake empirical research based on the above reaction function, the selection of variables to be included in $X_{i}$ for equation (2) becomes critical. In a general classification, significant explanatory variables of good governance can be grouped into economic, social, political and/or historical, and geographical categories. ${ }^{3}$

Based on Tobler (1970), and the hypothesis that "everything is related to everything else, but near things are more related than distant things," the geographical determinant or spatial spillover of governance quality on neighboring countries, or countries located in the same region, can be assessed. ${ }^{4}$ Many geographically proximate countries-despite different initial conditions ${ }^{5}$ - tend to exhibit similarities in the quality of their institutions reflecting spatial spillover. Indeed, countries are affecting each other not only through time, but also through their locations (Dubin 1998).

\section{MEASURES OF SPATIAL AUTOCORRELATION}

Against this background, and with the goal of identifying the influence of governance indicators across countries in a particular geography, this study estimates spatial dependence through a class of spatial autocorrelation modeling techniques.

\section{A. Moran's I}

One of the common tests of spatial autocorrelation is the Moran's I test originally developed by Patrick Moran (1950). Spatial autocorrelation is demonstrated by the notion of "connection" among nearby locations in space. Conceptually, this connection is driven by certain characteristics or "signals"

\footnotetext{
3 For further reading on the determinants of country governance performance, refer to Quibria (2014).

4 This is commonly referred to as the first law of geography.

5 Such conditions may refer to country economic, social, or natural resource context, such as income, education levels, legal origin, ethnicity background, or mineral resource endowments that define the initial position of the country.
} 
propagated by the entities or units in a particular geography or region Such signal manifestations across units result in spatial interdependencies, measured by the spatial autocorrelation and can potentially be complex due to its multidimensionality and multidirectional characteristic.

Moran's I is defined as

$$
\mathrm{I}=\left(\frac{N}{W}\right)\left(\frac{\sum_{i} \sum_{j} \mathrm{w}_{i j}\left(\mathrm{x}_{i}-\bar{x}\right)\left(\mathrm{x}_{j}-\bar{x}\right)}{\sum_{i}\left(\mathrm{x}_{i}-\bar{x}\right)^{2}}\right)
$$

- $\quad$ where $N$ is the number of spatial units indexed by $i$ and $j$;

- $\quad x$ is the variable of interest (governance in this case);

- $\bar{x}$ is the mean of $x$;

- $\quad \mathrm{w}_{i j}$ is a matrix of spatial weights with zeroes on the diagonal (i.e., $\mathrm{w}_{i j}=0$ ); and

- $\quad W$ is the sum of all $w_{i j}$.

The value of I crucially depends on the assumptions built into the spatial weights' matrix $\mathrm{w}_{i j}$. The idea is to construct a matrix that accurately reflects assumptions about the spatial phenomenon in question. A common approach is to give a weight of 1 if two locations are neighbors, and 0 if otherwise, though the definition of neighbors can vary. Another common approach might be to give a weight of 1 to $k$ nearest neighbors, 0 otherwise. An alternative is to use a distance decay function for assigning weights with weights declining with distance. Sometimes the length of a shared border-referred to as contiguity-is used for assigning different weights to neighbors.

\section{B. Spatial Econometric Technique}

As a more formal test, the study estimates a linear regression model that accounts for spatial dependence among the observations-empirically investigating the validity of equation (2). Spatial econometric models, which measure spatial autocorrelation of observations through the spatial autoregressive (SAR) specification, are employed.

The SAR specification, as depicted in Pace and LeSage (2006), is as follows:

$$
\begin{aligned}
& y=\rho W y+X \beta+\varepsilon \\
& y=\left(I_{n}-\rho W\right)^{-1} X \beta+\left(I_{n}-\rho W\right)^{-1} \varepsilon \\
& \varepsilon \sim N\left(O_{n \times 1}, \sigma^{2} I_{n}\right)
\end{aligned}
$$

- The dependent variable vector $y$ is of dimension $n$ by 1 , containing governance performance scores for each country.

- $\quad$ The $n$ by $k$ matrix $X$ contains observations on various explanatory variables (referred to as a set of characteristics of country $i$ that determine preferences), including a constant term vector. The k by 1 vector $\beta$ are associated regression parameters.

- The $n$ by 1 "spatial lag vector," Wy, reflects an average of the governance performance scores from neighboring countries as defined/specified by the matrix $W$. The associated scalar parameter $\rho$ (rho) reflects the strength of spatial dependence. When the scalar parameter $\rho$ takes on a value of zero, the model simplifies to the conventional linear regression model. 
- $\quad$ Finally, we assume the $\mathrm{n}$ by 1 disturbance vector $\varepsilon$ contains independent, normally distributed terms with a vector mean zero $\left(\mathrm{O}_{n \times 1}\right)$, constant variance, $\left(\sigma^{2}\right)$.

The basic idea underpinning these models is that the weight in the spatial parameter estimate is tracking the distance between countries in terms of its geographical coordinates. For example, Figure 1 would be tracking the countries (projected longitudinal and latitudinal coordinates) within the area of the circle that would have greatest influence on any given country, for example, the Philippines, with the dots indicating the surrounding countries.

To operationalize the spatial weights matrixw, this study adopts a row-normalized matrix in which the element $\mathrm{w}_{i j}=1$ if country $j$ belongs to the 10 nearest neighbors of country $i$ in the sample, and 0 otherwise.

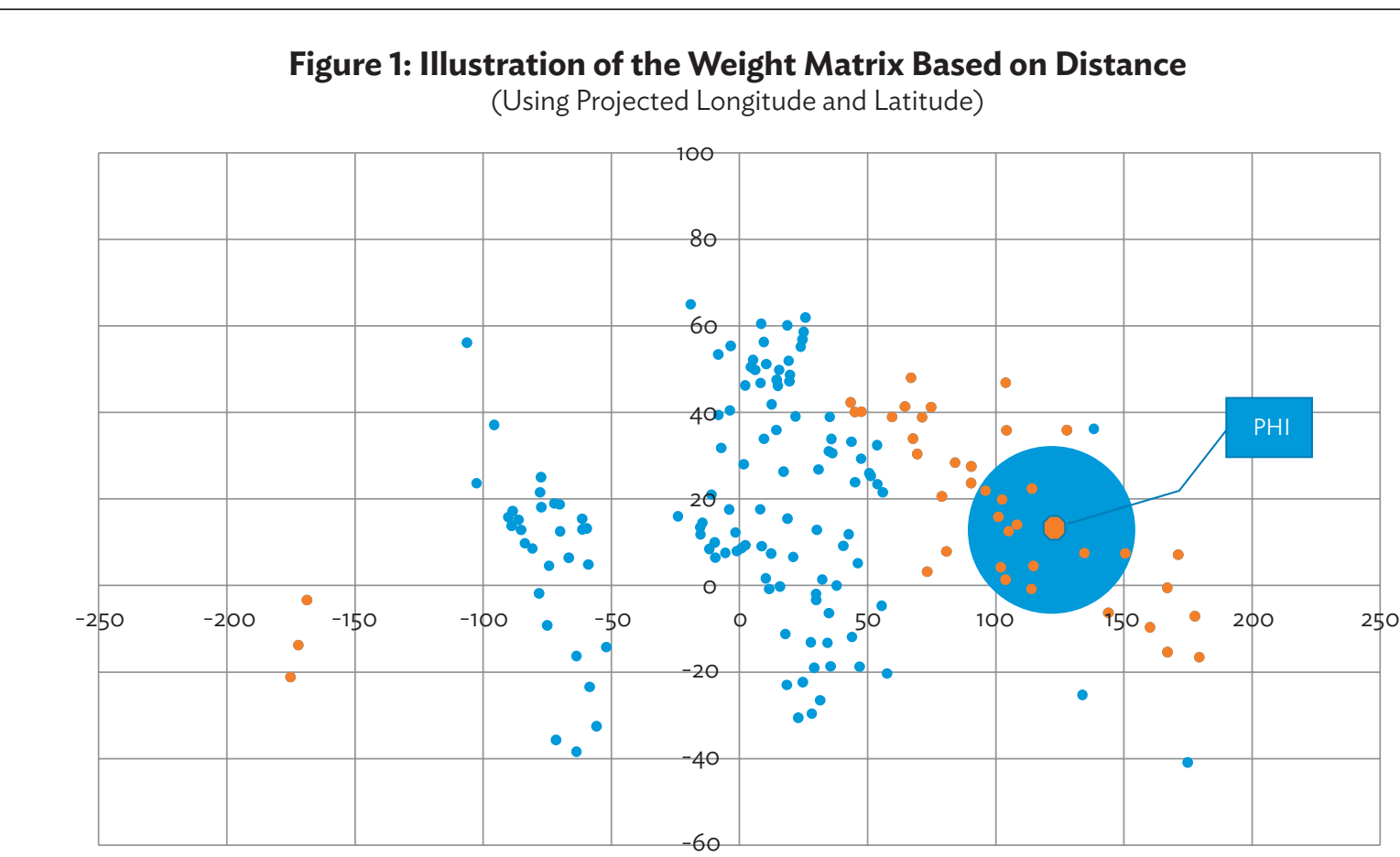

Source: Google Dataset Publishing Language, Country Guide and authors' calculations.

\section{Interpreting the Parameter Estimates}

In the spatial dependence model, the estimated parameter interpretation in ordinary least-squares is not valid. In principle, the dependence being tested in the model expands the information set to include evidence from neighboring countries. The spatial dependence model triggers a simultaneous movement or interaction across countries' governance performance, and this is determined by the characteristics of those countries and others as well. Any change in the characteristics of neighboring countries-that set in motion changes in governance performance-will impact governance scores of neighboring countries, and so on.

Since the impact of changes in an explanatory variable not only stops at the "home country," but also emanates over all countries, it is desirable to find a summary measure of these spillover impacts. Pace and LeSage (2006) calculated scalar summary measures that averaged these impacts across all observations/countries. They demonstrated that a change in a single explanatory variable in country $i$ has a "Direct effect" on country $i$ as well an "Indirect effect" on other countries $j \neq i$ in a spatial lag model. The "Average Direct Effect"-averaged over all $n$ countries - provides a summary measure of the impact arising from changes in the $i^{\text {th }}$ observation of variable $x$. The "Average Direct Effect" measures the impact on the governance score of a particular country from changing an explanatory variable $x$ in all other countries, or the impact of changing an explanatory variable in a particular country on the governance score of all other countries. 
As an illustration (which will be discussed further in the results section of the paper), if country $i$ increases its income per capita level, what will be the average impact on the governance performance in country $i$ ? This measure will also take into account feedback effects that arise from the change in the $i^{\text {th }}$ country's income per capita on governance score of neighboring countries in the system of spatially dependent countries.

Note that the Average Direct Effects are different from the estimates of the response parameters, $\beta$, in the SAR model due to the feedback effects that arise as a result of impacts passing through neighboring countries and back to the country itself. ${ }^{6}$

\section{Related Studies}

Some limited studies started to test institutional spillover effects empirically. Seldadyo et al. (2009) found a strong relationship between governance and locational similarity using maximum likelihood function values and Bayesian posterior model probabilities, with the spatial arrangement of countries in the sample best described by a spatial weights matrix based on the 10 nearest neighbors of every country in their sample. Hosseini and Kaneko (2012) adopted several spatial econometric approaches and revealed that spatial governance spillover can explain about $20 \%$ of governance quality of countries using contiguity as criteria to build their spatial weights matrix.

\section{DEFINING VARIABLES AND DATA REQUIREMENTS}

While there has been no consensus to the meaning of governance, the challenge is even greater when it comes to measuring it. Kaufman et al. (1999) extend the World Bank definition by stressing that the traditions and institutions through which authority is exercised includes "the process by which governments are selected, monitored and replaced; the capacity of the government to effectively formulate and implement sound policies; and the respect of citizens and the state for the institutions that govern economic and social interactions among them."

This, in turn, sets the framework for the Worldwide Governance Indicators ${ }^{7}$ (WGIs) divided into (i) voice and accountability, (ii) political stability and absence of violence, (iii) government effectiveness, (iv) regulatory quality, (v) rule of law, and (vi) control of corruption. Each of the pair-wise indicators captures three main themes as shown in Table $1 .{ }^{8}$ The strength of this framework is its reductionist simplicity and easy application across countries. Its weakness lies in its very nature of being a perception-based set of indicators that reflect reality subject to the various biases and subjective assessments.

\footnotetext{
6 For a detailed discussion of the implications of the SAR model specification-contrasting against the simple ordinary least squares estimation, outlining the feedback mechanisms from explanatory variables to the governance dependent variable, and showing detailed interpretation of the parameter estimates - refer to Pace and LeSage (2006).

7 The WGIs data set covers more than 200 countries over the period 1996-2018 and comprises six aggregate indicators polled across experts, business people, and citizens, and from 30 existing data sources. For a summary of data considerations, see Quibria (2014).

8 For a definition of the indicators, see Appendix 1.
} 
Table 1: Worldwide Governance Indicators-Dimensions and Criteria

\begin{tabular}{ll}
\hline Dimension (Worldwide Governance Indicators) & \multicolumn{1}{c}{ Criteria } \\
\hline $\begin{array}{l}\text { 1. Voice and Accountability } \\
\text { 2. Political Stability and Absence of Violence/ } \\
\text { Terrorism }\end{array}$ & $\begin{array}{l}\text { Political regime } \\
\text { The process by which governments are selected, monitored, } \\
\text { and replaced }\end{array}$ \\
\hline $\begin{array}{l}\text { 3. Government Effectiveness } \\
\text { 4. Regulatory Quality }\end{array}$ & $\begin{array}{l}\text { State capacity } \\
\text { The capacity of the government to effectively formulate } \\
\text { and implement sound policies }\end{array}$ \\
\hline $\begin{array}{l}\text { 5. Rule of Law } \\
\text { 6. Control of Corruption }\end{array}$ & $\begin{array}{l}\text { Legal framework } \\
\text { The respect of citizens and the state for the institutions that } \\
\text { govern economic and social interactions among them }\end{array}$ \\
\hline
\end{tabular}

Source: The Worldwide Governance Indicators and authors' interpretations.

The six dimensions of governance should not be thought of as being somehow independent of one another. One might reasonably think for example that:

- better accountability mechanisms lead to less corruption, or

- that a more effective government can provide a better regulatory environment, or

- that respect for the rule of law leads to fairer processes for selecting and replacing governments and less abuse of public office for private gain.

Considering such interrelationships, the six dimensional measures of governance are positively correlated strongly across countries.

To test for spatial dependence of governance among different countries, the $2018 \mathrm{WGI}$ data set in Kaufmann et al. (1999) is used. A governance index that is constructed as the non-weighted average of the various components of governance is employed. Index and governance dimension score estimates range from -2.5 to +2.5 , where a higher score reflects better governance. Even though the Kaufmann index is bounded, in most regressions, this study follows previous studies on the determinants of cross-country differences in governance and treats it as a non-truncated variable.

The other control or explanatory variables in equation (4) have been selected based on the results of previous studies (Leeson and Dean 2009; Seldadyo et al. 2009; Hosseini and Kaneko 2012). These variables - together with the expected signs of their associated parameters-are (i) income per capita (positive parameter sign); (ii) trade openness (positive parameter sign); (iii) education (positive parameter sign); (iv) the country's religious information (positive parameter sign); (v) legal origin (positive parameter sign); and (vi) relation to the natural resource condition of a country (negative parameter sign). ${ }^{9}$

There are 154 countries included in the world sample set used in this study, while the Developing Asia set excludes Australia, Japan, and New Zealand.

To enhance data availability and avoid reverse causation problems, data on these explanatory variables have been arithmetically averaged for the period 2005-2015.

9 Detailed technical description of the variables is as follows: (i) income as measured by average gross domestic product (GDP) per capita; (ii) trade openness (trade, imports + exports, as percent of GDP); (iii) average years of schooling; (iv) country religious information refers to level of diversity in religious practices and general ethnicity measured as the fraction of declared Christians relative to country population; ( $v$ ) country legal origin reflecting the degree of state involvement, 1 if the country follows common law traditions, 0 otherwise; (vi) total natural resources rents (\% of GDP), sum of oil rents, natural gas rents, coal rents (hard and soft), mineral rents, and forest rents; and measure of peculiarity specific to developing Asia, 1 if country belongs to group defined as "Developing Asia," 0 otherwise. 


\section{RESULTS OF SPATIAL ANALYSIS}

\section{A. Geographical Dependencies Exist}

Figure 2 presents the results of Moran's I test. The test supports spatial dependence with the strongest impact and greatest persistence on voice and accountability, and weakest on political stability. It is evident that governance spatial spillover across countries subsides the farther away countries are from each other.

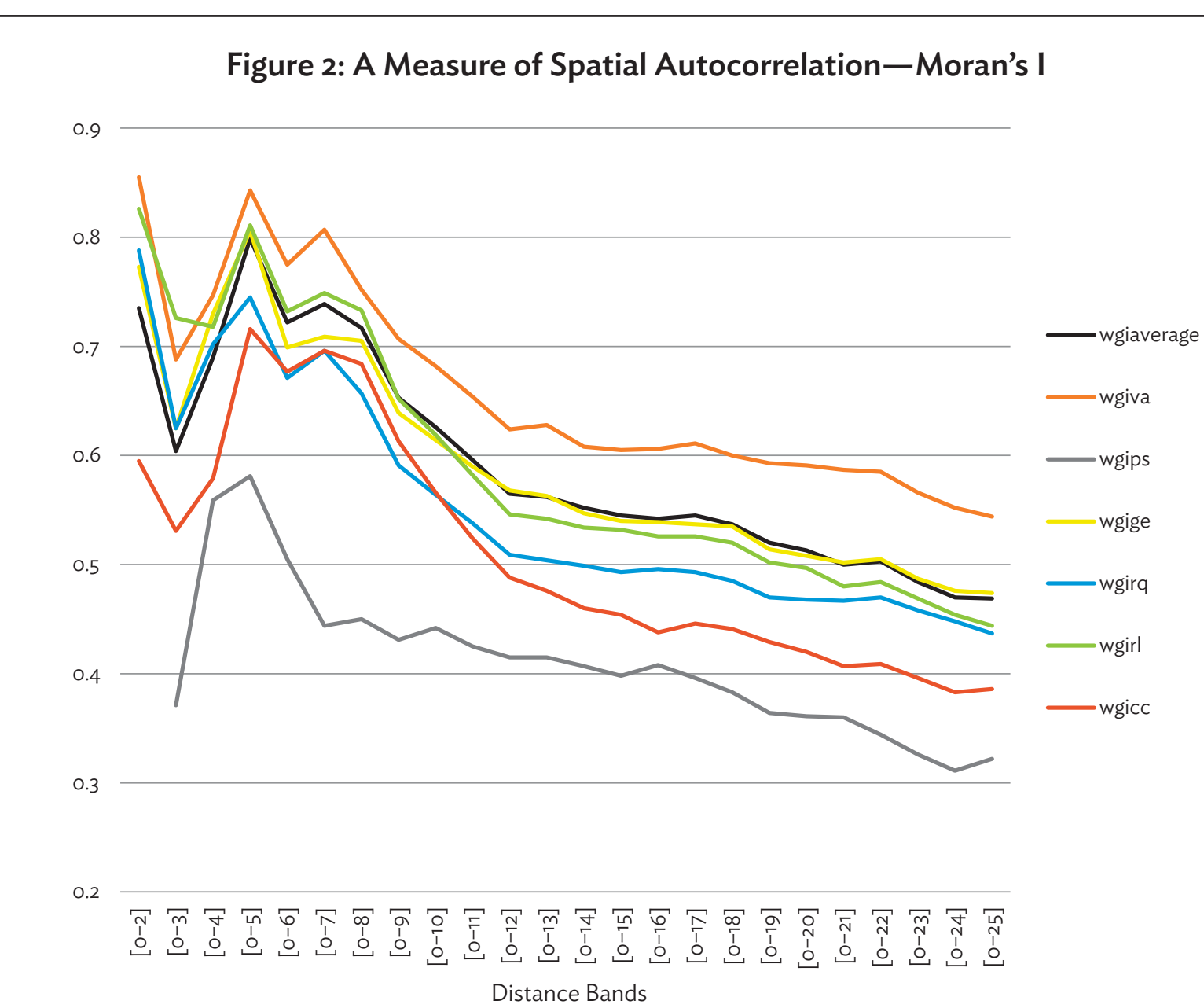

Source: The Worldwide Governance Indicators and authors' calculations.

Table 2 summarizes the spatial regression results showing that spatial spillover of institutions exists in SAR models using the WGls governance index and six dimensions as dependent variables. ${ }^{10}$ Regardless of their statistical significance, rho estimates, which encapsulate spatial spillover of institutional quality, are mostly positive showing the positive impact of countries' institutions on each other. ${ }^{11}$

10 The detailed spatial regression results are presented in Appendix 2.

11 This paper followed the robustness of results assessment done by Seldadyo et al. (2009) and Hosseini and Kaneko (2012) in terms of control variable usage, weight matrix specification, and number of neighbors. To test whether this paper's conclusions are sensitive to the set of explanatory variables, dummy variables for the country geographic classification have been considered. In the regressions shown in Appendix 2, the dependent variable is treated as a non-truncated variable. Detailed robustness test results are available upon request to the authors. 
Table 2: Measuring Governance Spatial Spillover

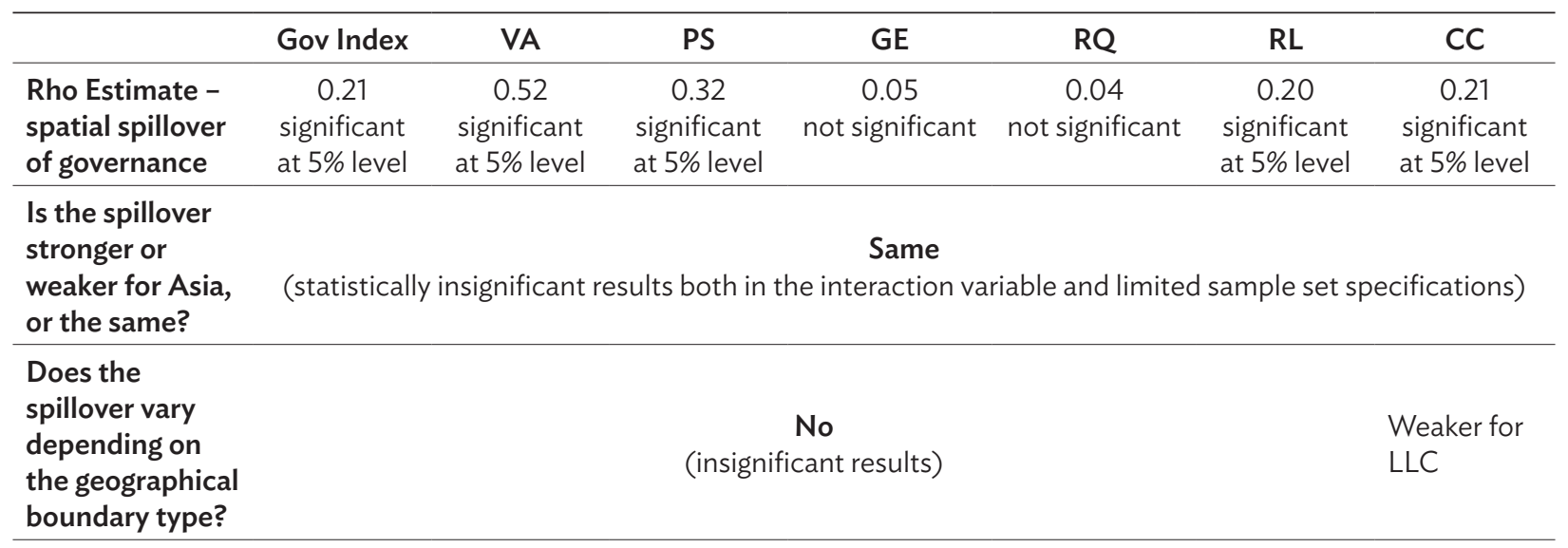

LLC = landlocked country, WGI = Worldwide Governance Indicators.

Note: Gov Index refers to governance index derived from a simple unweighted average of the six WGIs: VA: Voice and Accountability, PS: Political Stability, GE: Government Effectiveness, RQ: Regulatory Quality, RL: Rule of Law, and CC: Control of Corruption.

Source: World Bank World Development Indicators, The Worldwide Governance Indicators, and authors' calculations.

These geographical or spatial dependencies may be implicitly driven by certain institutional transmission mechanisms. One potential mechanism of institutional spillover is learning. Neighboring countries can observe the activities of nearby countries and improve on successful ideas at a lower cost than if they had to look further abroad to find them.

In addition to the learning mechanism, globalization also serves as a channel for governance spatial spillover. Parallel trends in the direction of political democratization and economic globalization in the last quarter of 20th century provide some evidence for this, although perhaps the influence has waned somewhat since the beginning of the 21 st century. ${ }^{12}$

Immigration is another channel for governance spatial spillover. The ability of a government to implement policies that disenfranchise the country's population is a priori constrained by opportunities for residents to relocate to other countries where it is easier to relocate to than more distant countries. This is better known as the "neighborhood constraint theory."

To explore whether spatial impact across Developing Asia is any different from global findings, the study estimates a model specification with an interaction variable of the spatial lag vector, and a Developing Asia dummy variable and a SAR model for Developing Asia using a limited sample set. As reported in the second row of Table 2, the findings were statistically insignificant. The study also tried to evaluate governance spillover by factoring the type of geographical boundary or contiguity be it landlocked or archipelagic (third row of Table 2), but also found results to be statistically insignificant. Accordingly, there is no evidence to suggest that Asia is any different in terms of geographical spillovers vis-à-vis the rest of the world.

\section{B. Spatial Spillover Most Evident in the Political Regime Dimension}

The spatial spillover estimates point to the political regime dimension of governance (refer to categories identified in Table 1) where countries exhibit the highest spatial dependence as reflected by a higher rho in the first row of Table 2. Given the breakdown and focusing on its constituent parts, the strongest spatial impact is Voice and Accountability $(r h o=0.5)$ followed by Political Stability $(r h o=0.3)$.

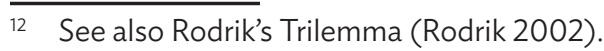


To explain the results, it is apparent that there is no easily accepted interpretation as other governance variables could be as easily influenced by the neighborhood. One possible explanation could be that the voice and accountability dimension reflect the largest gap between Asia's results with respect to the group of countries with the highest WGI standards (in this case, that of the Organisation for Economic Co-operation and Development). Given the gap, it may be that voice and accountability represents a low-hanging fruit of sorts as far as the cost required to achieve relative improvement, as there is a pent-up demand across countries in those lagging regions. Once a particular country in the region relaxes those constraints that hold back progress on this dimension, it can have an extraordinarily strong influence on neighboring countries. In line with this interpretation, when there is less score distance or gap across the particular governance indicator, the influence of geography may be much more subdued.

The geographical dependencies in terms of the voice and accountability dimension, as defined in WGIs, may manifest in several directions that result in either positive/constructive or negative/destructive outcomes. To draw from recent experiences, both at the national and international levels, consider the power of free speech and transparency in transforming a country's governance landscape. For instance, the "Arab Spring," "Me Too," and "Black Lives Matter" movements have shown that voice and accountability does spill over across national boundaries and promote potentially dramatic governance changes.

In contrast, other governance dimensions such as government effectiveness cannot be easily "imported" from learning from a neighboring country as there is a capacity development dimension in this indicator that can only improve through time as the quality of the civil service improves. In other words, this is more of a sticky or sluggish variable as it takes a degree of learning that typically takes more time and is a resource-intensive adaptation process than simple replication.

An interesting follow-up to this result is what feature of the institutional transmission mechanism would drive such a country to follow an observed state action or behavior from other countries in the region. The Tiebout competition channel may provide a simple answer. Drawing from globalization and the idea that states are in some form of competition to attract foreign business and direct investment can provide important incentives. Improving the business environment by increasing transparency and accountability may lead to positive changes spreading throughout a geographic region.

Interestingly, the high spatial dependence observed in the WGI political regime dimension follows along the line of argument of Acemoglou and Robinson (2019). They consider the role of institutions in pursuit of liberty and how to develop a fine balance between the at times oppressive forces of the state, and the moderating tendencies of society or citizens. There is no steady state in their framework, but rather continuous interaction between state and society to ensure that there is a narrow corridor or "sweet spot" where countries develop in liberty. In this framework, empowering citizens with voice and accountability is critical for development and serves as part of the checks and balances to ensure countries operate within the domains of liberty.

\section{Income Level Significantly Determines Governance Performance}

The spatial regression framework also lends itself to analyzing other determinants of governance performance. Table 3 presents the results of the spatial regression between the six WGIs as well as the composite or unweighted average as dependent variables with different initial conditions, and development outcomes as independent variables. 
Table 3: Determinants of Governance

\begin{tabular}{lccccccc}
\hline & Gov Index & VA & PS & GE & RQ & RL & CC \\
\hline Income Per Capita & + & + & & + & + & + & + \\
\hline Trade Openness & & & + & & & & \\
\hline Level of Education & + & & + & + & & & \\
\hline Ethnic Diversity & + & + & + & & & + & + \\
\hline Legal Origin & + & + & & & & - & -
\end{tabular}

Notes:

“+” denotes significant positive relationship, “-” denotes significant negative relationship, and a blank field denotes no significant relationship.

Gov Index refers to governance index derived from a simple unweighted average of the six WGIs: VA: Voice and Accountability, PS: Political Stability, GE: Government Effectiveness, RQ: Regulatory Quality, RL: Rule of Law, and CC: Control of Corruption.

Sources: World Bank World Development Indicators, University of Ottawa Faculty of Law, Pew Research Global Religious Landscape, and authors' calculations.

Apart from the outright spatial dependence, results show that income levels (as a representation of economic development status) have significant explanatory power on the governance composite indicator. This implies that higher income may increase demand for good governance..$^{13}$ Implicit in this logic is the intuitive idea that at very low levels of income per capita, citizens are primarily focused on meeting their subsistence plus other basic requirements. Only with higher levels of income per capita can citizens organize themselves locally, or even politically, and as such increase their voice in terms of demand for other priorities - such as better employment opportunities, schools, and health care-and hold governments accountable to deliver such improved services. It is therefore likely that with improved livelihoods and a growing politically motivated and better organized middle class, economic growth will, in turn, result in improved governance including better provision of services and less tolerance for corruption, among others. ${ }^{14}$

\section{Feedback Effects of Income Level on Governance Performance}

As results point to the significant impact of a country's economic development on governance performance, it may be gleaned that the degree of geographical or spatial dependencies may also be motivated by economic outcomes.

As shown in Appendix 2, the spatial autoregressive (SAR) model allows for the calculation of feedback effects. A country in a particular neighborhood increases governance performance whenever its income per capita level rises. This refers to the direct effect; results in Appendix 2(i) show that income has a positive direct contribution to country governance performance..$^{15}$ In addition, there is a need to take into account feedback effects that arise from the change in a country's income per capita on governance score of neighboring countries in the system of spatially dependent countries. Such is the indirect effect,

13 Though positive in relationship, the speed of this adjustment tapers off (as reflected by the negative coefficient estimate on the square of per capita income variable) and may point to a certain convergence point for countries wanting to improve their governance quality.

14 This paper's empirical methodology does not directly account for the widely perceived bi-directional causality between governance and economic development. The simultaneity issue is circumvented indirectly by using "lagged" values of the explanatory variables.

15 In Appendix 2(i) it can be observed that the direct impact corresponds to a 0.000037 increase in governance performance of a certain country whenever this country registers a dollar increase in its per capita income. 
which measures the impact arising from one country raising its income per capita on governance scores of all other countries, on average. Results in Appendix 2(i) show that 21\% of the total average effect of income per capita can be associated to an indirect feedback mechanism-i.e., there is significant spillover effect of improved economic performance in one country to the governance performance of neighboring jurisdictions.

A probable manifestation of this proposition is through the emulation channel of institutional spillover. Emulation may be considered as a geographic mechanism in the sense that some regional "big player" countries (in terms of economic size, such as the United States in the Americas, and Germany in Europe,) may be perceived to lead in terms of potential institutional and policy goals. Other neighboring countries can closely benefit from emulation and be positively influenced so as to raise the governance bar to a higher level.

Another mechanism of institutional spatial spillover is manifested through economic communities and economic zones that may potentially lead to an improved collective economic outcome. Several economic communities promote cooperation and encourage their members to harmonize across institutional standards to improve their economic performance and eventually converge institutionally. For example, The Association of Southeast Asian Nations has been working continuously on its intraand inter-regional free trade policies that can be seen contributing to the steady growth of per capita income in its geographical scope. This, in turn, encourages knowledge sharing on governance best practices among member countries, even incentivizing further the state's ability to emulate behavior.

Acemoglou and Robinson (2012), in Why Nations Fail, partly underpinned the interplay between economic and political institutions. Inclusive economic institutions create an enabling environment through broad-based opportunities and incentives for people to invest, innovate, and contribute to productivity-enhancing economic activity. However, over the long run, these economic opportunities can only be sustained by inclusive political institutions to ensure law enforcement, prevent the monopolization of power by vested interests ("political capture"), and remove obstacles for continuous economic and political change. The interaction between inclusive economic and political institutions is key in their framework, and too often political creative destruction ends up halting economic innovation and change. In this framework, political stability in terms of its ability to espouse change is fundamental.

\section{E. Other Drivers of Country Governance Performance}

Further results on the significance of other explanatory or control variables are shown in Table 3. Trade openness only showed significant positive relationship to the political stability dimension of governance. A free trade regime may encourage international market price settings in a country, thereby generating greater predictability in incentives and solidify property rights-two important attributes of a highquality institutional framework.

The level of education appears important for aggregate governance performance, political stability, and government effectiveness. Higher levels of educational achievement increase human capital, contribution to output and income; hence, produces over time more informed electorates that better monitor government actions.

The variable capturing ethnic diversity figures significantly for the political regime (voice and accountability, and political stability) dimension of governance similar to findings of La Porta et al. (1999). Norms and beliefs, which are inhospitable to markets or trust, prevent countries from building institutions to encourage trade and investment (North 1994; Knack and Keefer 1995; Shirley 2008). 
The legal origin regressor shows significant positive relationship with voice and accountability, rule of law, and control of corruption-mostly impacting the legal framework of a country.

The negative relationship to resource rent is associated with what is known as the "resource curse" wherein the abundance of natural resource in a country can seriously decrease all dimensions of institutional quality. Natural resource dependence can damage or erode institutions indirectly by removing incentives to reform, improving infrastructure, or even establishing a well-functioning tax bureaucracy by provoking a fight to control resource rents (Harford and Klein 2005), in line with the negative coefficient in this paper.

\section{CONCLUSIONS}

\section{A. Summary of Key Findings}

The key finding of the paper is that the spatial spillover of good governance of countries on their neighbors is especially evident in voice and accountability and political stability pillars. It has been observed that countries within close proximity are influenced by one another, and any member of the neighborhood or region will progress in conjunction with the progress of others. In other words, the institutional quality of neighboring countries goes hand in hand.

This study also investigated other determinants of institutional quality, especially in the global context. The most important economic determinant of institutional quality, as defined in WGIs, is the income level of countries - operating on institutional quality through both supply and demand factors. Income per capita determines the availability of resources to build good institutions, and also generates a larger demand for quality of institutions. Feedback mechanisms have also been observed wherein any change in the characteristics (especially in income level) of neighboring countries can, in turn, set in motion changes in governance performance that will impact governance scores of neighboring countries.

\section{B. Policy Applications}

As a policy implication, countries-especially those in the same region-have a greater ability to influence each other, including improving the quality of their institutions. Therefore, regional political and economic communities can play critical roles in improving cooperation and providing good opportunities for joint institutional improvement programs. Recognizing the role of spatial spillovers, and the rich variance within and across subregions and countries in these groupings, suggests that there is value continuing to forge and deepen regional cooperation initiatives, including sharing lessons and experiences across countries, including within a South-South dialogue and equally important across various subregions in Asia. This favors the comparative advantage of institutions of regionalism in effectively sharing ideas and transferring knowledge across borders.

Finally, voice and accountability should be considered systematically across governance activities in order to ensure that citizens can be organized and empowered to ensure constructive dialogue across a range of areas that are important to them. This may lead to a better recognition of government engagement with civil society organizations as a means of checks and balances on the authority of the state, ensuring that political institutions are inclusive and, ultimately, strengthen development outcomes. 



\section{APPENDIX 1: DEFINITIONS OF WORLDWIDE GOVERNANCE INDICATORS}

The Worldwide Governance Indicators (WGIs) project constructs aggregate indicators of six broad dimensions of governance:

\section{A. Voice and Accountability}

Reflects perceptions of the extent to which a country's citizens are able to participate in selecting their government, as well as freedom of expression, freedom of association, and a free media

\section{B. Political Stability and Absence of Violence/Terrorism}

Measures perceptions of the likelihood of political instability and/or politically motivated violence, including terrorism

\section{Government Effectiveness}

Reflects perceptions of the quality of public services, the quality of the civil service and the degree of independence from political pressures, the quality of policy formulation and implementation, and the credibility of the government's commitment to such policies

\section{Regulatory Quality}

Reflects perceptions of the ability of the government to formulate and implement sound policies and regulations that permit and promote private sector development

\section{E. Rule of Law}

Reflects perceptions of the extent to which agents have confidence in and abide by the rules of society, and in particular, the quality of contract enforcement, property rights, the police, and the courts, as well as the likelihood of crime and violence.

\section{F. Control of Corruption}

Reflects perceptions of the extent to which public power is exercised for private gain, including both petty and grand forms of corruption, as well as "capture" of the state by elites and private interests. 


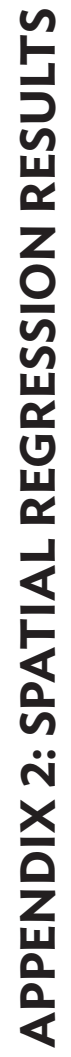

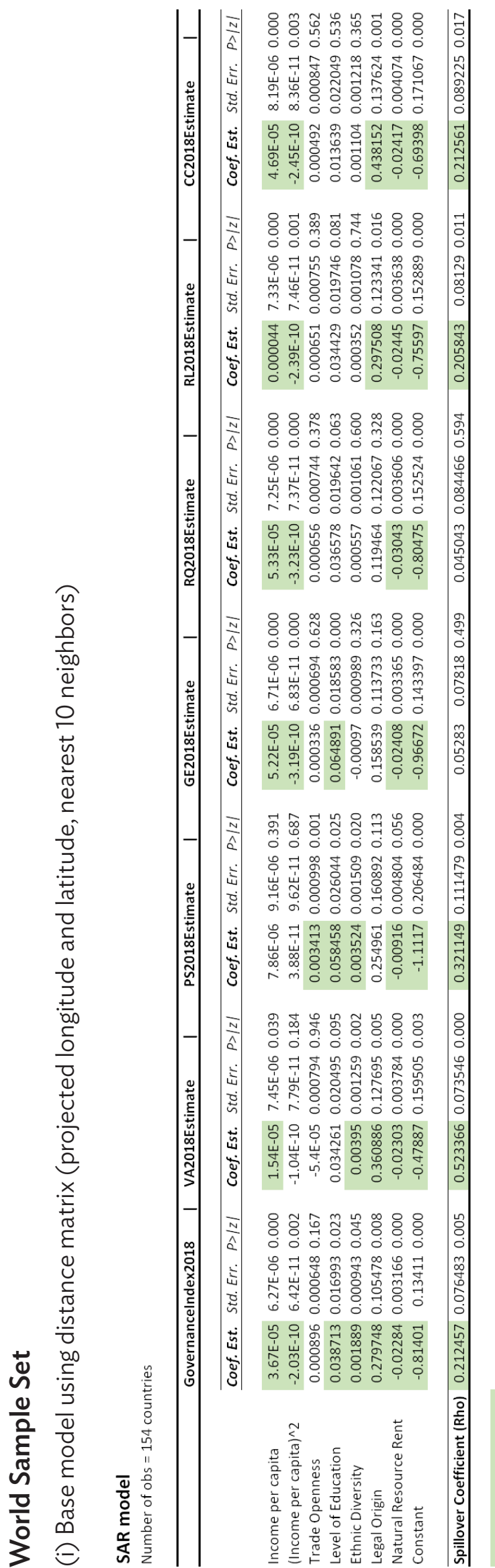




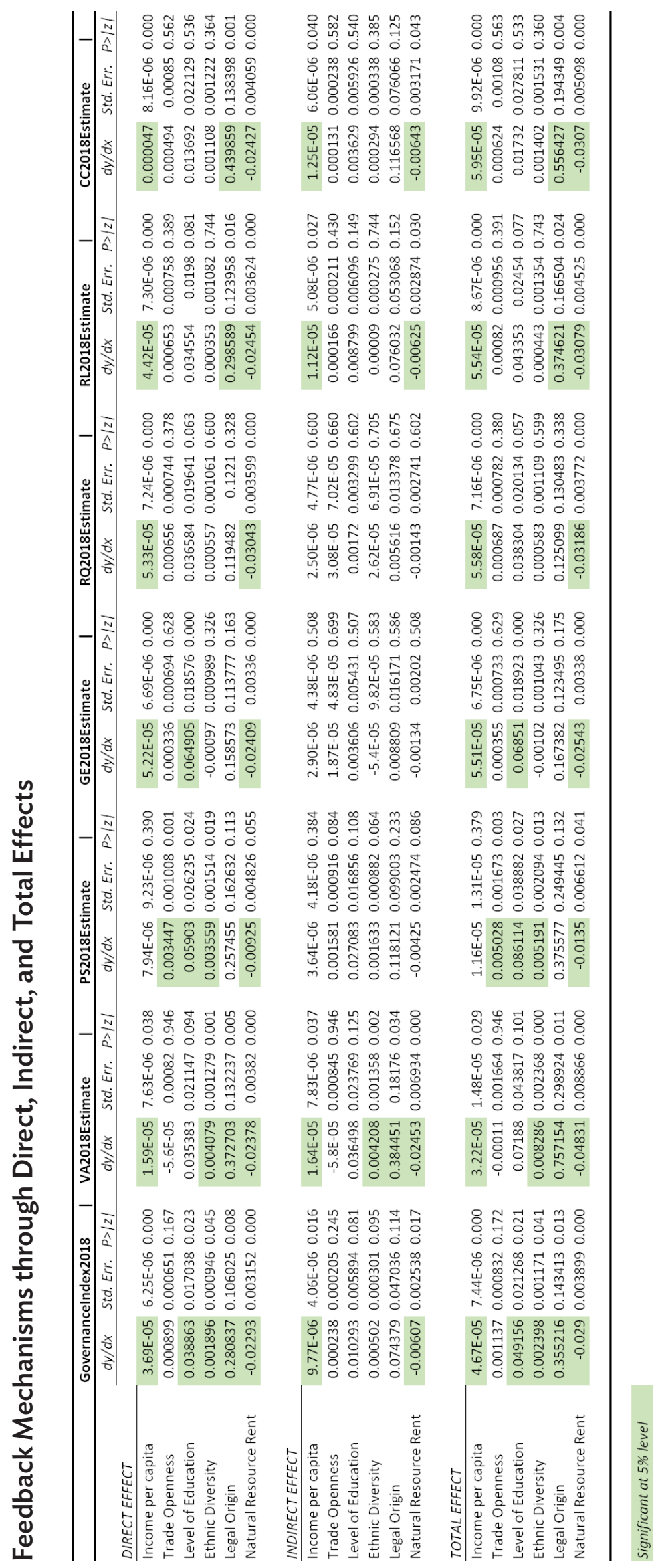




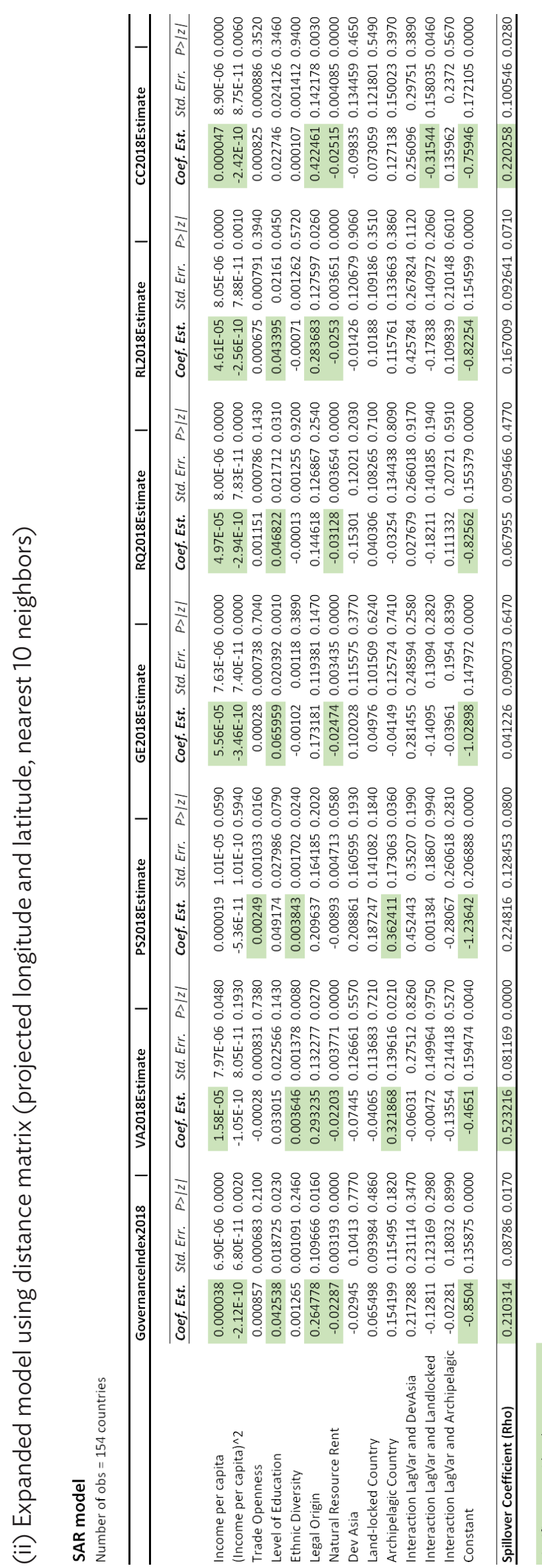



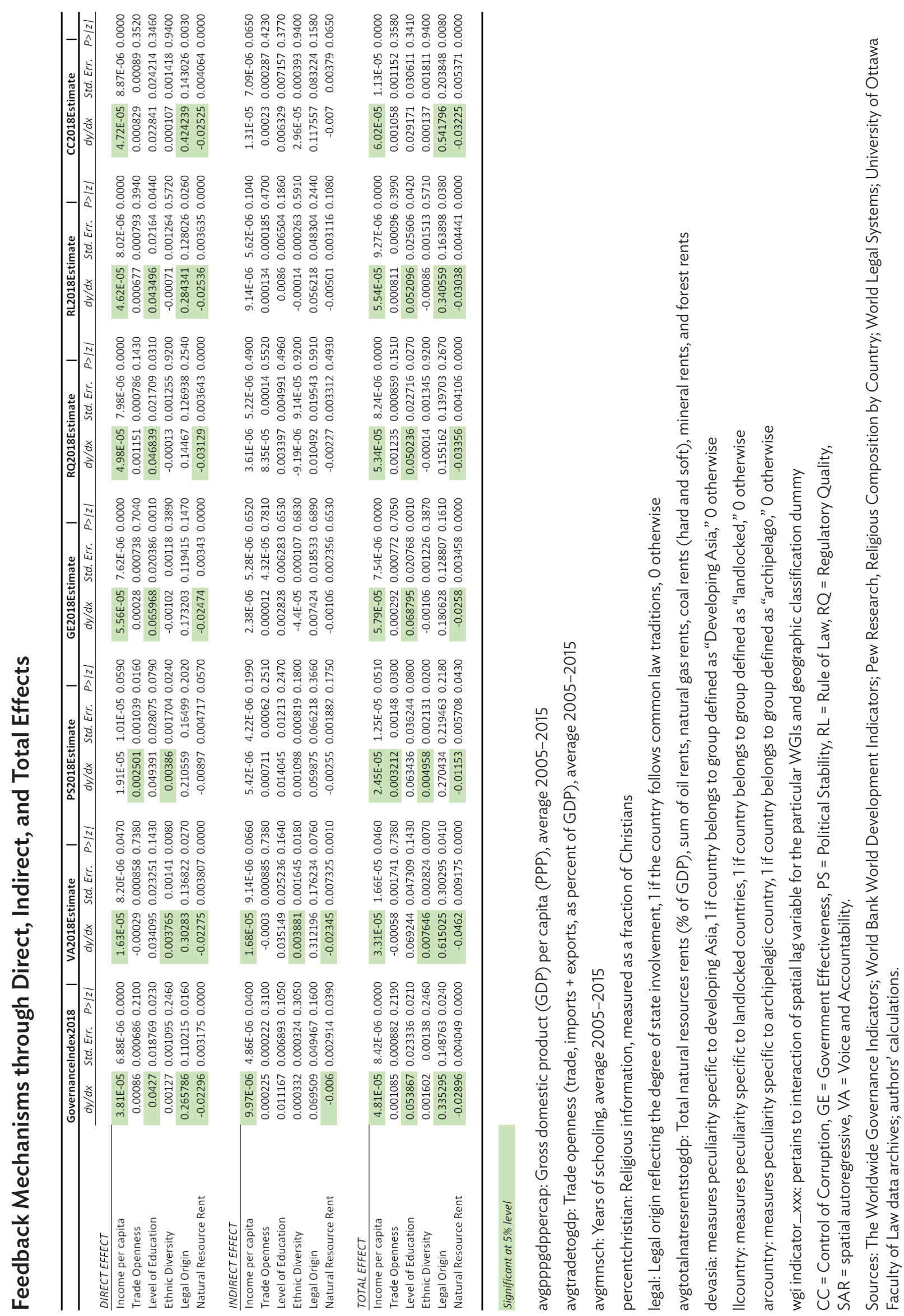


\section{REFERENCES}

D. Acemoglu et al. 2001. The Colonial Origins of Comparative Development, An Empirical Investigation. American Economic Review 91(5): pp. 1369-1401.

D. Acemoglu et al. 2002. Reversal of Fortune, Geography and Institutions in the Making of the Modern World Income Distribution. Quarterly Journal of Economics 117: pp. 1231-1294.

D. Acemoglu and J.A. Robinson. 2012. Why Nations Fail: The Origins of Power, Prosperity and Poverty. First edition. New York: Crown.

D. Acemoglu and J.A. Robinson. 2019. The Narrow Corridor: States, Societies, and the Fate of Liberty. New York: Penguin Press.

A. Ades and R. Di Tella. 1996. The Causes and Consequences of Corruption: A Review of Recent Empirical Contributions. IDS Bulletin 27(2) pp. 6-11.

L. Anselin. 2006. Spatial Econometrics. In Palgrave Handbook of Econometrics, T.C. Mills and K. Patterson (eds). Terence Palgrave Macmillan: Basingstoke.

J.K. Brueckner. 2000. A Tiebout/Tax-Competition Model. Journal of Public Economics. Volume 77, No. 2: pp. 285-306.

J.K. Brueckner. 2003. Strategic Interaction Among Governments, An Overview of Empirical Studies. International Regional Science Review 26: pp. 175-188.

R.H. Coase. 1960. The Problem of Social Cost. Journal of Law and Economics 3(1): pp. 1-44.

R.A. Dubin. 1998. Spatial Autocorrelation: A Primer. Journal of Housing Economics 7(4): pp. 304-327.

W. Easterly and R. Levine. 2003. Tropics, Germs, and Crops: How Endowments Influence Economic Development. Journal of Monetary Economics 50: pp. 3-39.

S. Globerman and D. Shapiro. 2002. Global Foreign Direct Investment Flows: The Role of Governance Infrastructure. World Development 30: pp. 1899-1919.

Google Dataset Publishing Language. Country Coordinates, Country Guide (accessed August 2019). https://developers.google.com/public-data/docs/canonical/countries_csv.

T. Harford and M. Klein. 2005. Aid and the Resource Curse. The World Bank Group, Private Sector Development Vice Presidency, Note 291.

S. Holmberg et al. 2009. Quality of Government: What You Get. Annual Review of Political Science. Vol. 12: pp. 135-161.

M. Hosseini and S. Kaneko. 2012. Spatial Spillover of Governance and Institutional Quality: A Spatial Econometric Approach. Development Discussion Policy Paper, Graduate School for International Development and Cooperation (IDEC) DP2 Series Vol. 2 No.3. Hiroshima University: Higashi-Hiroshima. 
D. Kaufmann et al. 1999. Governance Matters. Policy Research Working Paper No. WPS 2196. Washington, DC: World Bank.

D. Kaufmann et al. 2009. Governance Matters VIII: Aggregate and Individual Governance Indicators, 1996-2008. Policy Research Working Paper No. 4978. Washington, DC: World Bank.

S. Knack and P. Keefer. 1995. Institutions and Economic Performance: Cross-Country Tests, Using Alternative Institutional Measures. Economics and Politics 7(3): pp. 207-227.

R. La Porta et al. 1999. The Quality of Government. Journal of Law, Economics, and Organization 15(1): pp. 222-279.

P.T. Leeson et al. 2006. Contagious Capitalism. Working Papers 06-04 Classification. Department of Economics, West Virginia University.

P.T. Leeson and A.M. Dean. 2009. The Democratic Domino Theory: An Empirical Investigation. American Journal of Political Science 53(3): pp. 533-551.

P. Mauro. 1995. Corruption and Growth. Quarterly Journal of Economics 110(3): pp. 681-712.

K. Moloney. 2009. Public Administration and Governance: A Sector-Level Analysis of World Bank Aid. Journal International Review of Administrative Sciences 75(4): pp. 609-627.

P.A.P. Moran. 1950. Notes on Continuous Stochastic Phenomena. Biometrika Vol. 37, No. 1/2 (June ): pp. 17-23.

S.W. Mukand and D. Rodrik. 2005. In Search of the Holy Grail: Policy Convergence, Experimentation, and Economic Performance. American Economic Review 95(1): pp. 374-383.

K.M. Murphy et al. 1993. Why Is Rent-Seeking So Costly to Growth? The American Economic Review 83(2). Papers and Proceedings of the Hundred and Fifth Annual Meeting of the American Economic Association: pp. 409-414.

D.C. North. 1971. Institutional Change and Economic Growth. Journal of Economic History 31(1): pp. 118-125.

D.C. North. 1994. Institutions Matter. Economic History 9411004. University Library of Munich: Germany. EconWPA.

J. O'Loughlin et al. 1998. The Diffusion of Democracy, 1946-1994. Annals of the Association of American Geographers 88: pp. 545-574.

O. Olsson and D. A. Hibbs. 2005. Biogeography and Long-Run Economic Development. European Economic Review 49: pp. 909-938.

R.K. Pace and J.P. LeSage. 2006. Interpreting Spatial Econometric Models. Paper presented at the Regional Science Association International North American meetings. Toronto, Canada.

Pew Research. Religious Composition by Country. https://assets.pewresearch.org/wp-content/uploads/ sites/11/2012/12/globalReligion-tables.pdf (accessed August 2019).

M.G. Quibria. 2014. Governance and Developing Asia: Concepts, Measurements, Determinants, and Paradoxes. ADB Economics Working Paper Series No. 388. Manila: ADB. 
D. Rodrik. 2002. Feasible Globalizations. KSG Working Paper Series. RWP02-029.

D. Rodrik et al. 2004. Institutions Rule: the Primacy of Institutions Over Geography and Integration in Economic Development. Journal of Economic Growth 9: pp. 131-165.

H.J. Seldadyo et al. 2010. Geography and Governance: Does Space Matter? Papers in Regional Science. 89(3).

M.M. Shirley. 2008. Institutions and Development. Edward Elgar Publishing Limited Vol. 45.

B.A. Simmons and Z. Elkins. 2004. The Globalization of Liberalization: Policy Diffusion in the International Political Economy. American Political Science Review 98: pp. 171-189.

R.S. Sobel and P.T. Leeson. 2007. The Spread of Global Economic Freedom. In Economic Freedom of the World, edited by J. Gwartney and R. Lawson. Fraser Institute.

H. Starr. 1991. Democratic Dominoes: Diffusion Approaches to the Spread of Democracy in the International System. Journal of Conflict Resolution 35: pp. 356-381.

W.R. Tobler. 1970. A Computer Movie Simulating Urban Growth in the Detroit Region. Economic Geography 46: pp. 234-240.

University of Ottawa. World Populations and Legal Systems: Faculty of Law Data Archives. https://web.archive.org/web/20070105123426/http://www.droitcivil.uottawa.ca/world-legal-systems/ eng-population.php (accessed August 2019).

M.D. Ward and K.S. Gleditsch. 2002. Location, Location, Location: An MCMC Approach to Modeling the Spatial Context of War and Peace. Political Analysis 10: pp. 244-260.

Wikipedia. Moran's I article. https://en.wikipedia.org/wiki/Moran\%27s_I (accessed August 2019).

World Bank. 1992. Governance and Development. Washington, DC: The World Bank.

World Bank. World Development Indicators. http://datatopics.worldbank.org/world-developmentindicators/ (accessed July 2019). 


\section{The Role of Geography in Shaping Governance Performance}

Governance has a spatial dimension due to spillovers and resource flows across juridical boundaries. This paper finds that governance in a given country - manifested most clearly through voice and accountability-exhibits a positive relationship with those in neighboring countries. Feedback mechanisms are traced in that any change in the income level of a country can affect its governance performance and also impact the governance scores of neighboring countries. This phenomenon is observed in the "Arab Spring," "Me Too," and "Black Lives Matter" cross-border movements. The observed geographical dependencies strengthen the case for regional political and economic communities, as they can play critical roles in enhancing cooperation and providing opportunities for institutional development.

\section{About the Asian Development Bank}

ADB is committed to achieving a prosperous, inclusive, resilient, and sustainable Asia and the Pacific, while sustaining its efforts to eradicate extreme poverty. Established in 1966, it is owned by 68 members -49 from the region. Its main instruments for helping its developing member countries are policy dialogue, loans, equity investments, guarantees, grants, and technical assistance. 